\title{
DYNAMIC ANALYSIS \\ OF THE TUBULAR LINEAR ACTUATOR WITH PERMANENT MAGNETS
}

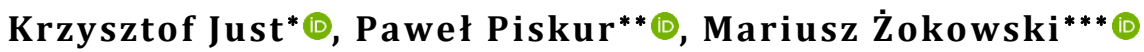 \\ * 1st Airlift Base (1BLTr), Żwirki i Wigury 1c Str., 00-909 Warsaw, Poland, email: justk5@op.pl; \\ ORCID ID 0000-0003-2725-8178 \\ ** Polish Naval Academy, Faculty of Mechanical and Electrical Engineering, Śmidowicza 69 Str., \\ 81-127, Gdynia, Poland; e-mail: p.piskur@amw.gdynia.pl; ORCID ID 0000-0002-8823-4316 \\ ${ }^{* * *}$ Air Force Institute of Technology, Division for Aircraft Composite Structures, Księcia Boleslawa 6 Str., \\ 01-494 Warsaw, Poland, zokowm@itwl.pl; ORCID ID 0000-0002-5307-9483
}

\begin{abstract}
In this paper a results of a transient analysis of the linear actuator is presented. The linear actuator consist of the three cylindrical unmovable coils surrounded by a soft ferromagnetic case, a runner made from sequence of ferromagnetic and permanent magnet rings. The model of the linear actuator was implemented into two software: the Comsol Multiphysics and the Matlab-Simulink. Both environments are commonly used in simulation analysis, but the first one uses Finite Element Method (FEM) and the second one uses Ordinary Differential Equations (ODE). Moreover, the dynamic model was analysed in Matlab-Simulink software with value of electromagnetic phenomena implemented from Comsol Multiphysics. Comparison was made due to the time needed for calculation, accuracy of the simulation model as well as the as utility for further optimization process.
\end{abstract}

Key words:

modelling electromagnetic linear actuator, permanent magnet linear motor, computer simulation.

Research article

(C) 2019 Krzysztof Just, Paweł Piskur, Mariusz Żokowski This is an open access article licensed under the Creative Commons Attribution-NonCommercial-NoDerivatives 4.0 license (http://creativecommons.org/licenses/by-nc-nd/4.0/) 


\section{INTRODUCTION}

The linear electromagnetic motors are commonly used in many robotic and automatic systems $[6,7,9]$. The main advantages are the simple design structure, fast response for the input signal, lack of any mechanical transmission from the rotation movement to the linear one [8]. On the other hand there is a not enough mathematical description and algorithms how to design the linear actuator [10]. This is due to the nonlinearity connected with nonlinear distribution of magnetic field in space, current dependency on the coil inductance [1]. What is more coil inductance depends on the runner position and the runner velocity as well [11]. The linear mathematical model of electromagnetic actuator is sufficient in some considerations, but not if a more accurate calculations are needed [13]. In this paper nonlinearity of the magnetic field distribution is presented as a function of discrete position of the runner. Because of the long time needed for calculation process, the received data was implemented in the Matlab-Simulink package and then, the dynamic analysis was performed. The results of the simulations were compared for both packages. This kind of analysis allows to take into consideration nonlinearity of the magnetic field and the actuator dynamic. As a results of simulation analysis of the electromagnetic force, the runner velocity is presented and compared with experimental data achieved from laboratory model.

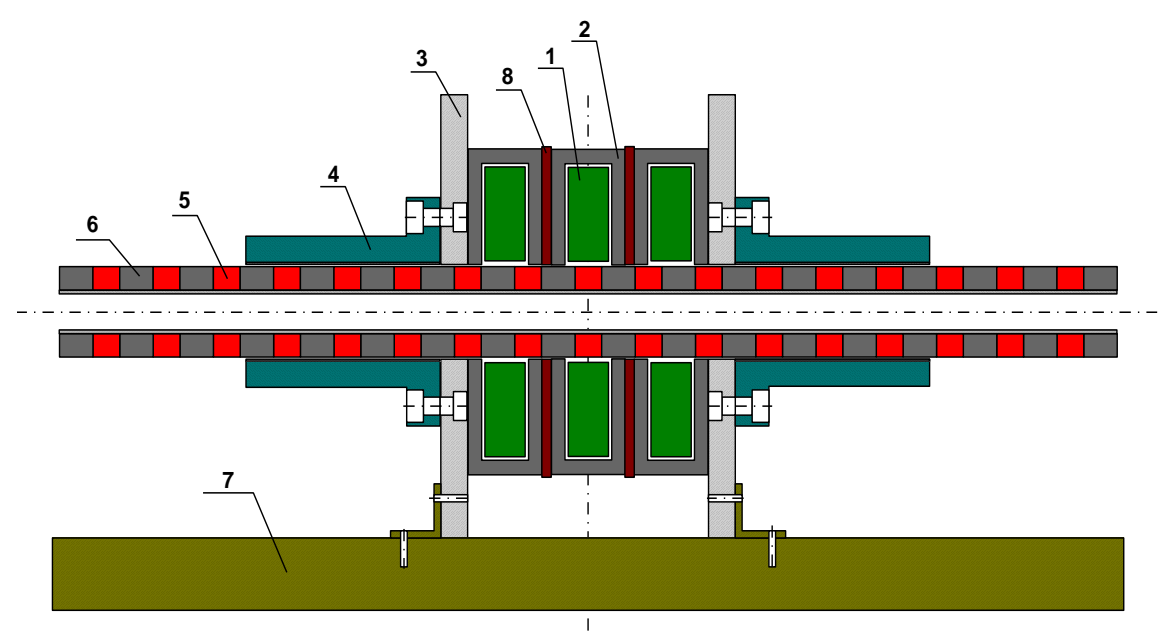

Fig. 1. The scheme of the three-coils permanent magnet tubular linear motor: 1 - coil, 2 - ferromagnetic case, 3 - holder, 4 - linear bearing, 5 - permanent magnet, 6 - ferromagnetic ring, 7 - fixed link, 8 - separator 
The scheme of the three-coils tubular linear actuator is presented in the fig. 1. The electromagnetic actuator consists of the three coils and runner with permanent magnets rings and ferromagnetic gaskets. The coils can be supplied with different algorithm (for example: unipolar or bipolar). The coil magnetic field interacts with magnetic field from the movable permanent rings. The length of the runner depends on the task the actuator is to being designed. Presented method of simulation is independent from the length of the runner. No matter how long the runner is desired, the result of ferromagnetic force can be calculated in the same way. The runner inertia will change proportionally to its length. Some assumption have been taken, connected with eddy current and heating losses. It was assumed that their impact on the accuracy of the simulation model is negligibly small.

\section{MATHEMATICAL AND SIMULATION MODEL}

The magnetic coils energy and the electric energy are coupled and their interchange depends also on the position of the runner [13]. A distribution of the magnetic field is not uniform neither in the air gap nor in the ferromagnetic parts of the devices so it must be modelled as a continuous in space. The hysteresis of ferromagnetic parts and the nonuniform distribution of the magnetic field should be included (see fig. 4-7). The non-analytic relation between the magnetic field strength $H$ and the magnetic flux density $B$ can be described as a table with series values and then introduced into computer model $[3,4,8]$. If the runner velocity is not high, the air pressure resistance may be omitted. Also electrical properties may be accepted as discrete in space, as the current changes in coils are comparatively slow. As the motion process of the runner is short, the temperature increase is small and the process may be assumed as an isothermal and all material parameters to be constant, unless the process is repetitive $[5,12]$. To summarize, there are many nonlinear phenomena, and they are strongly coupled.

For the actuator dynamic evaluation the two electro-magnetic and mechanic equations have been taken into consideration [2]:

$$
\begin{gathered}
u(t)=R \cdot i(t)+\frac{d \Psi(t)}{d t} \\
m \cdot \frac{d^{2} z}{d t^{2}}=F_{e}-F_{t}-F_{l o a d}
\end{gathered}
$$

1 (216) 2019 
where:

$u(t)$ - voltage supplying the coil [V];

$R$ - coil resistance $[\Omega]$;

$i(t)$ - coil current [A];

$\Psi \quad$ - magnetic flux in the air gap [Wb];

$z \quad$ - runner displacement [mm];

$m$ - runner mass [kg];

$F_{\text {load }}$ - additional resisting force [N];

$F_{e}$ - electromagnetic force [N];

$F_{t} \quad$ - friction force [N];

$t$ - time [s].

The magnetic flux $\Psi$ is a sum of two components:

$$
\Psi=\Psi_{m}+\Psi_{i}
$$

where:

$\Psi_{m}$ - magnetic flux from permanent magnet rings;

$\Psi_{i} \quad$ - magnetic flux from the coil.

The magnetic flux was computed in two dimensional simulation model in the Comsol Multiphysics package (fig. 4-7). Because of the model symmetry, only a half of the device has been taken under consideration. The value of magnetic flux density (fig. 4-7) as a function of the runner displacement and as a function of the coil current has been implemented to the dynamic equation (4) and the simulation model has been completed in the Matlab-Simulink package (fig. 2 and 3).

$$
\left\{\begin{array}{l}
\frac{d i}{d t}=\frac{1}{\frac{\partial \Psi(i, z)}{\partial i}} \cdot\left(u-R \cdot i-\frac{\partial \Psi(i, z)}{\partial z} \cdot v_{z}\right) \\
\frac{d z}{d t}=v_{z} \\
\frac{d^{2} z}{d t^{2}}=\frac{1}{m} \cdot\left(F_{e}(i, z)-K_{d} \cdot v_{z}-K_{s}-F_{\text {load }}\right)
\end{array}\right.
$$




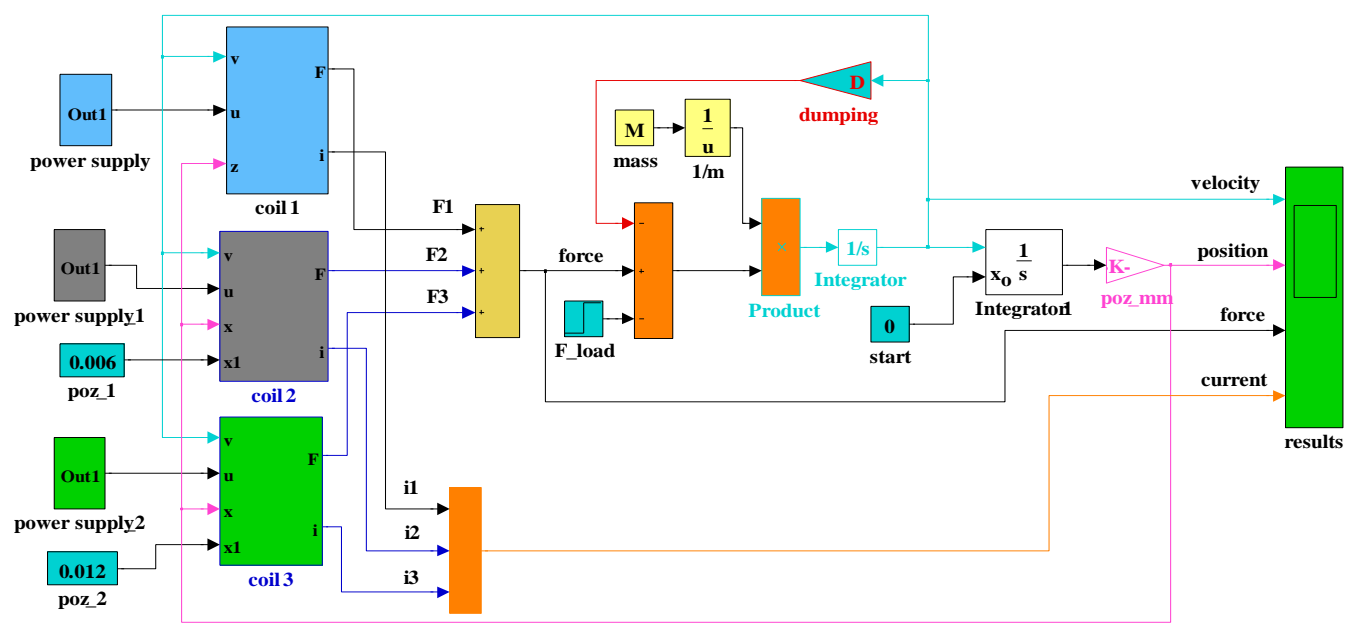

Fig. 2. The dynamic model of the three-coils actuator with magnetic field value implemented in the coil subsystem

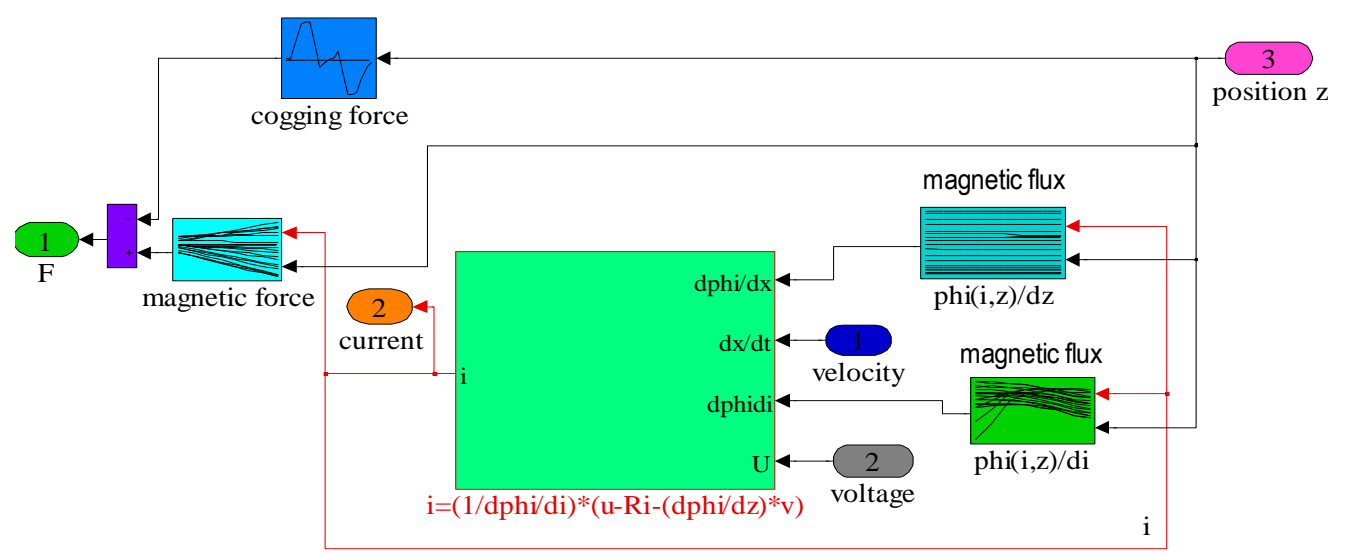

Fig. 3. The coil subsystem with magnetic field values evaluated from partial differential equations (resolved in Comsol Mutiphysics)

The three coils were supplied with a sequence of the current impulses with different time of duration (fig. 2). More technical details on impulse power suppliers are included in the articles $[1,4]$. For constant current in the middle coil the magnetic flux density was computed for different position of the core and depicted in the fig. 4-7. In this model a few physical phenomena are solved simultaneously. It can be useful to observe much output information in specific points of the device as a function of input construction data. 


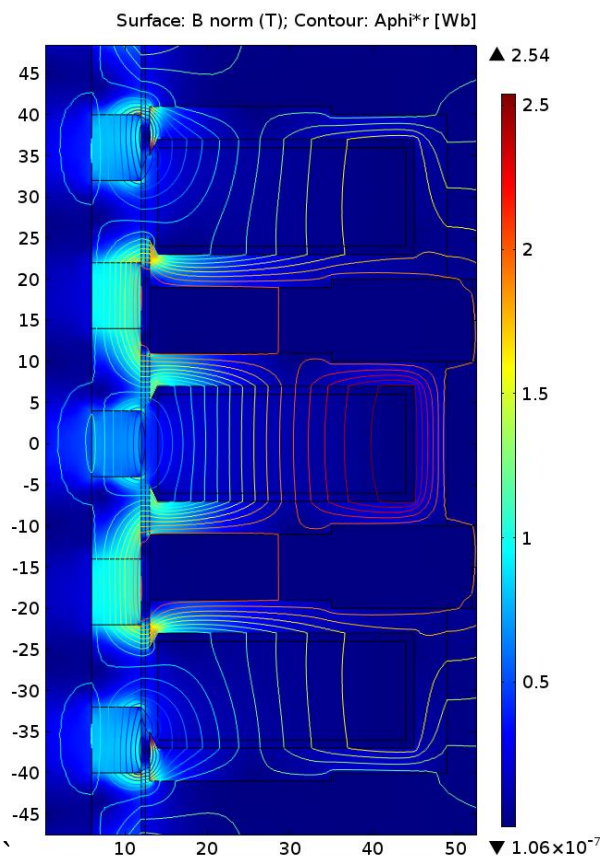

Fig. 4. Magnetic flux density distribution for the runner displacement $0 \mathrm{~mm}$

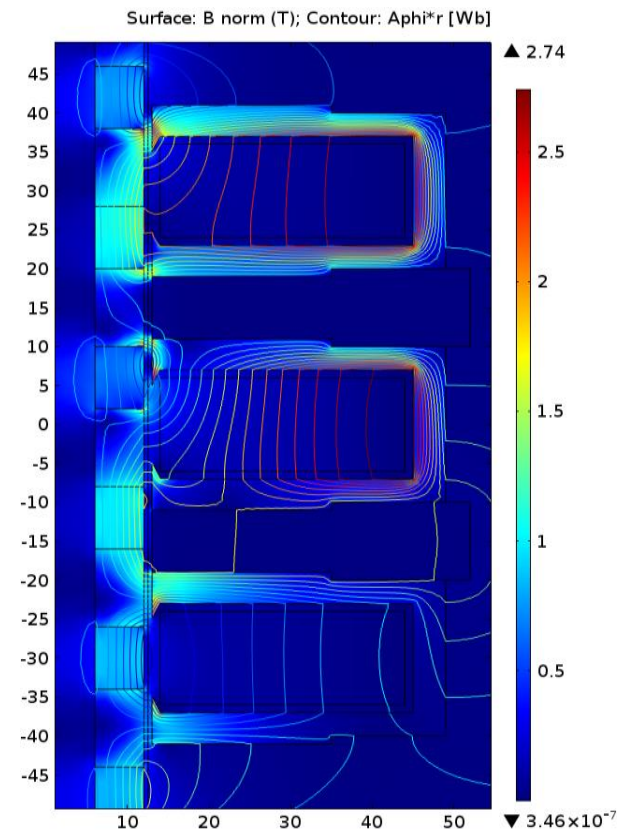

Fig. 6. Magnetic flux density distribution for the runner displacement $12 \mathrm{~mm}$

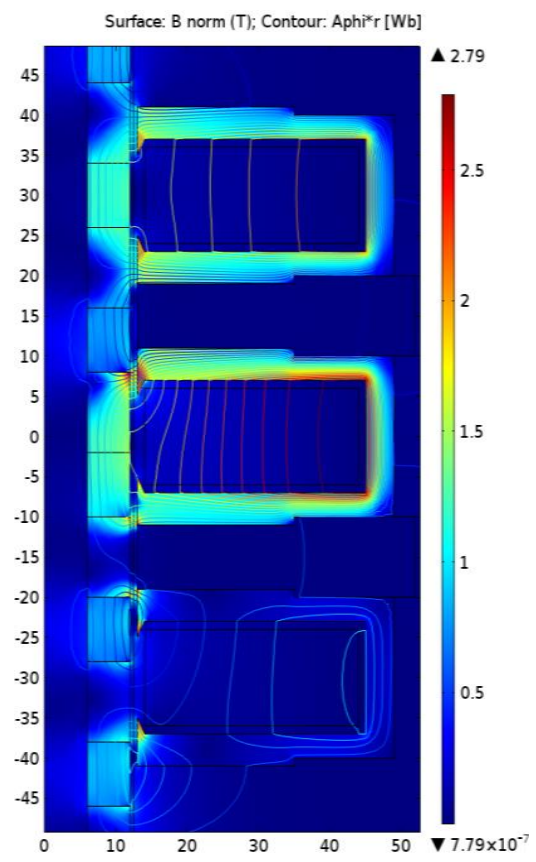

Fig. 5. Magnetic flux density distribution for the runner displacement $6 \mathrm{~mm}$

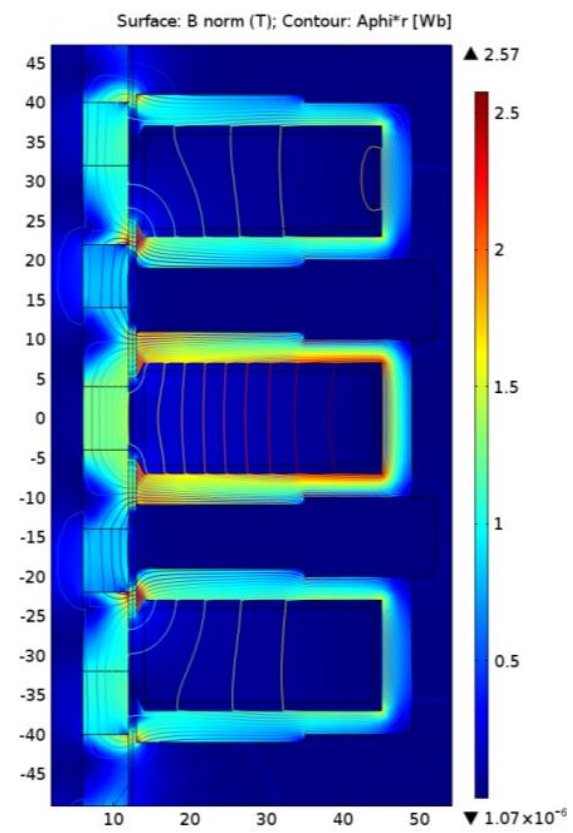

Fig. 7. Magnetic flux density distribution for the runner displacement $18 \mathrm{~mm}$ 
In the initial position of the runner (fig. 4), the magnetic field of the supplied coil is subtracted from the field made by the permanent magnet, then the ferromagnetic cases of the upper and lower coil near the air gap are the most saturated. After moving the runner from the centre of the coil to $12 \mathrm{~mm}$ (fig. 6), the highest saturation occurs in the yoke of the powered stator segment. After the movement of $18 \mathrm{~mm}$, the magnetic flux is distributed symmetrically in the elements of the tread and the ferromagnetic case of the central coil, flows from permanent magnets and stator windings add up, therefore the ferromagnetic case of the powered coil is the most saturated, and local saturation of the magnetic circuit in the area of the air gap is visible.

The comparison between dynamic model made in Comsol Multiphysics and the second one made in Matlab-Simulink with magnetic field distribution calculated in Comsol Multiphysics and implemented into the Matlab is presented in the fig. 8. Although the power supply was sequential, differences in the charts are probably caused by the redistribution of FEM mesh. There are some methods of generation FEM mesh for moving objects: reference configuration (ALE); Lagrangian approach; Eulerian approach and these methods will be analysed in the next step of investigation focusing on the re-meshing impact on accuracy.

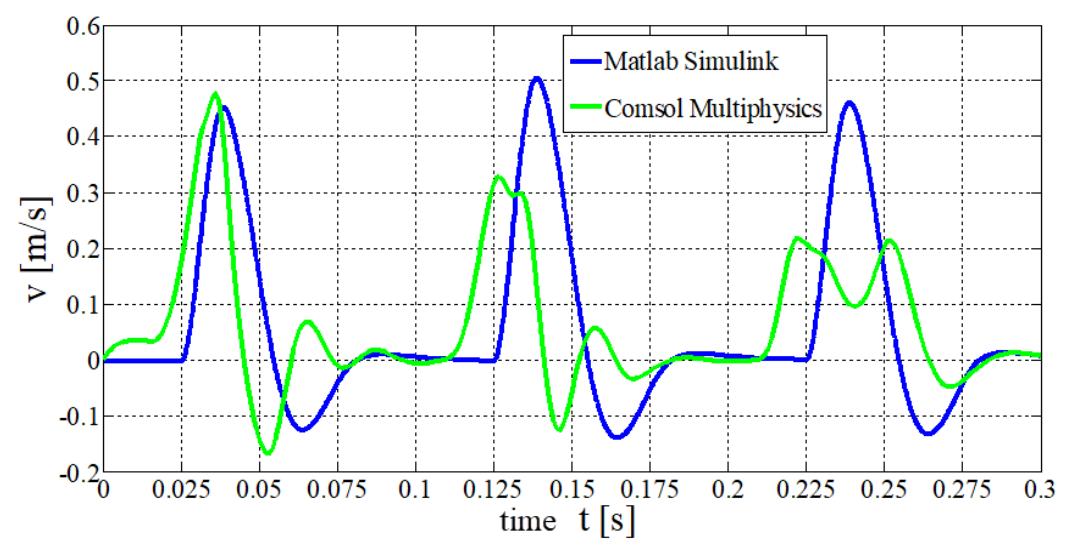

Fig. 8. Comparison of the runner velocity as a function of time calculated in two packages

\section{EXPERIMENTAL RESULTS}

Having the simulation results the laboratory model was built and the test stand was realised. The validation process was carried out on the laboratory test stand is presented in the fig. 9. The coil was made from 300 copper wires with the diameter of $1 \mathrm{~mm}$. The coil resistance R was equal $2.1 \Omega$, and the inductance $\mathrm{L}$ was $5.5 \mathrm{mH}$. 
The coil was supplied from the brushless PWM servo amplifier from the Advance Motion Control Company (AMC). The displacement of the core was measured with linear position potentiometer and the core velocity was calculated. For the current measurements the specialized current sensors 'center 223' were used. The real time system was used for control algorithm, measurements and gathering data.

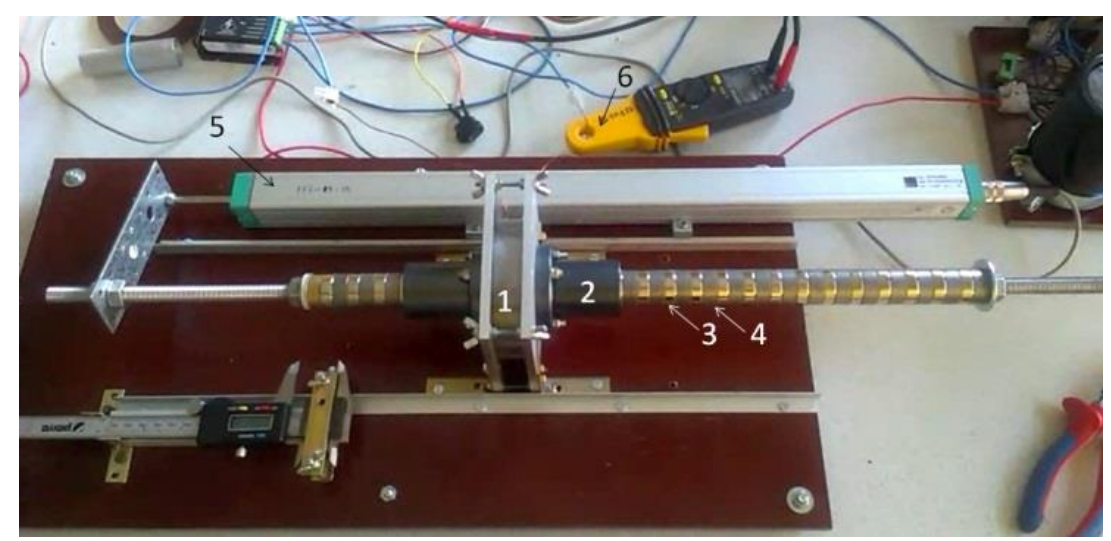

Fig. 9. The laboratory linear actuator permanent magnet tubular linear actuator: 1 - coils with ferromagnetic case, 2 - linear bearing, 3 - permanent magnet ring, 4 - ferromagnetic ring, 5 - position sensor, 6 - specialize current sensor 'center 223'

During the experiments, the actuator dynamics studied for several different frequency of the current pulses. It has been noticed that increasing the frequency of power pulses the runner's movement is more smoothly until the maximal frequency, when the supply pulses were missing. One of the example of velocity characteristic as a function of current pulses is shown in the fig. 10 .

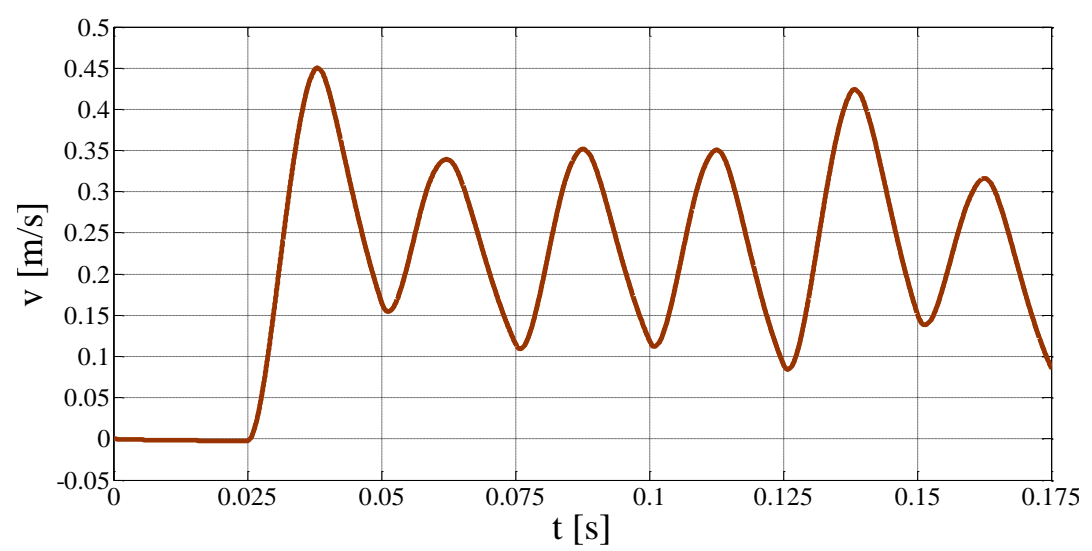

Fig. 10. The core velocity as a function of time for time current supplied $t=0.025 \mathrm{~s}$ 
In the fig. 10 there is a characteristic of velocity changes in time for current pulses generated with period $t=0.025 \mathrm{~s}$. If the coil supplied time decrease to $t=0.015 \mathrm{~s}$ the runner stops. This is due to the limitations in the construction of the stator windings (time constant of coils). As a result the current is not able to reach the maximal value, and the rise time is longer than the duration of the voltage pulse. When the next coil is switched on, there are braking forces from the coil where the current is still flowing, causing the runner to slow down. Control the pulse duration improves the smoothness of motion, there are increasingly smaller oscillations, which are clearly visible at lower power frequencies (fig. 8).

\section{CONCLUSIONS}

In this paper method of simulation of the linear actuator was described with focusing on both the construction and control data. The simulation model is presented, with a careful consideration of the hysteresis of ferromagnetic parts, and nonlinear distribution of the magnetic field. The number of assumptions and simplifications was limited due to the investigation of the influence of some part of the object and an future optimization process. A combination of the two programs (Comsol Multiphysics and Matlab) gives the powerful opportunity to analyse the object without building the prototype. It was shown that dynamic model implemented in Matlab-Simulink with nonuniformly distributed magnetic field achieved from Comsol Multiphysics gives better results than simulation only in FEM package. What is more, time simulation is shorter for presented method than in FEM package. For the verification process the laboratory test stand was designed and some result were depicted. In the future investigations the multidisciplinary model can be used for the control algorithm optimization process.

\section{REFERENCES}

[1] Chojnacki D., Falkowski K, Henzel M., The Analysis of Amplifier Module for Electric Drive, International Symposium on Electrodynamic and Mechatronic System, 2013, pp. 45-46.

[2] Gieras J. F., Piech Z. J., Tomczuk B., Linear synchronous motors, CRC Press, Taylor \& Francis Group, USA, 2011.

[3] Gosiewski Z., Henzel M., Falkowski K., Żokowski M., Numerical and Experimental Testing of Bearingless Induction Motor, 'Mechatronic Systems and Materials IV', Series 'Solid State Phenomena', 2013, Vol. 198, pp. 382-387, DOI: 10.4028/www.scientific.net/SSP.198.382.

1 (216) 2019 
[4] Grzeczka G., Szymak P., Analysis of Using Fuel Cell Technology for Autonomous Underwater Vehicle Power Supply, Proceedings of the 11th Wseas International Conference on Automatic Control, Modelling and Simulation: Controlling, Modelling and Simulation, Electrical and Computer Engineering Series, 2009, pp. 195-201.

[5] Kondratiuk M., Gosiewski Z., Comparison of Simulated and Measured Signals of the Electromagnetic Coil Launcher for Micro Aerial Vehicles, International Symposium on Electrodynamic and Mechatronic System, 2013, pp. 57-58, DOI: 10.1109/SELM.2013.6562978.

[6] Kondratiuk M., Gosiewski Z., Laboratory Stand of an Electromagnetic Multi-Coil Launcher for Micro Aerial Vehicles, 'Mechatronic Systems and Materials IV', Series 'Solid State Phenomena', 2013, Vol. 198, pp. 334-339, DOI: 10.4028/www.scientific.net/SSP.198.334.

[7] Ling Z., Ji J., Wang F., Bian F., Design and analysis of a field modulated magnetic screw for artificial heart, 'AIP Advances', 2017, Vol. 7, Issue 5, DOI: 10.1063/1.4975699.

[8] Piskur P., Tarnowski W. Just K., Model of the electromagnetic linear actuator for optimization purposes, 23rd European Conference on Modelling and Simulation, 2009, pp. 708-713.

[9] Szymak P., Morawski M., Malec M., Conception of Research on Bionic Underwater Vehicle with Undulating Propulsion, 'Mechatronic Systems, Mechanics and Materials', Series 'Solid State Phenomena', 2012, Vol. 180, pp. 160-166, DOI: 10.4028/www.scientific.net/SSP.180.160.

[10] Tarnowski W., Krzyzynski T., Maciejewski I., Oleskiewicz R., Poly-optimization: a paradigm in engineering design in mechatronics, 'Archive of Applied Mechanics', 2011, Vol. 81, Issue 2, pp. 141-156.

[11] Tomczuk B., Schröder G., Waindok A., Finite element analysis of the magnetic field and electromechanical parameters calculation for a slotted permanent magnet tubular linear motor, 'IEEE Trans. on Magnetics', 2007, Vol. 43, No. 7, pp. 3229-3236.

[12] Tomczuk B., Waindok A., Wpływ liczby faz na tętnienia siły magnetycznej w aktuatorze liniowym, 'Zeszyty Problemowe - Maszyny Elektryczne', 2009, No. 84, pp. 161-166 [Phase number influence on the magnetic force ripplesin a linear actuator — available in Polish].

[13] Waindok A., Tomczuk B., Reluctance network model of a permanent magnet tubular motor, 'Acta Mechanica et Automatica', 2017, Vol. 11, Issue 3, pp. 194-198, DOI: 10.1515/ama-2017-0029.

\section{ANALIZA DYNAMICZNA SILNIKA LINIOWEGO TUBOWEGO Z MAGNESAMI TRWAŁYMI}

\section{STRESZCZENIE}

W artykule przedstawiono model dynamiczny silnika liniowego tubowego z magnesami trwałymi na biegniku. Analizie poddano zmienne konstrukcyjne oraz zmienne sterowania. Przedstawiono sposób modelowania silnika liniowego z wykorzystaniem metody elementów skończonych w programie Comsol Multiphysics. Wyniki porównano z alternatywną metodą modelowania obiektów 
dynamicznych zaimplementowaną w środowisku Matlab-Simulink. W obu modelach symulacyjnych uwzględnione zostały nieliniowości pola magnetycznego oraz histereza namagnesowania ferromagnetycznych części silnika. Połączenie obu programów (Comsol Multiphysics i Matlab) umożliwia analizę parametrów silników liniowych bez potrzeby kosztownego budowania prototypów. Ponadto na podstawie przeprowadzonych analiz można stwierdzić, że model dynamiczny zaimplementowany w Matlabie z uwzględnieniem nieliniowości pola magnetycznego otrzymanej z Comsol Multiphysics jest dokładniejszy aniżeli model symulacyjny opracowany tylko metodą elementów skończonych. Wyniki obu metod porównano i zweryfikowano eksperymentalnie na opracowanym w tym celu stanowisku laboratoryjnym. Ocenie poddane zostały czasy symulacji pod kątem dalszej procedury optymalizacji konstrukcji i sterowania silnika liniowego.

\section{Słowa kluczowe:}

modelowanie liniowych silników elektromagnetycznych, silniki liniowe tubowe z magnesami trwałymi, symulacja komputerowa.

\section{Article history}

Received: $\quad 28.06 .2018$

Reviewed: 28.11.2018

Revised: $\quad 17.12 .2018$

Accepted: 18.12.2018 